\title{
STUDENTS' PERCEPTION ABOUT CLINICAL LEARNING ENVIRONMENT IN THE PRIMARY, SECONDARY AND TERTIARY MEDICAL FACILITIES
}

\author{
Dian Puspita Dewi*, Gandes Retno Rahayu**, Tri Nur Kristina* \\ * Fakultas Kedokteran Universitas Diponegoro, Semarang - INDONESIA \\ ** Fakultas Kedokteran, Kesehatan Masyarakat dan Keperawatan Universitas Gadjah Mada, Yogyakarta - INDONESIA
}

\begin{abstract}
Background: Learning environment is an important factor in learning process and can affect students' competence and work-readiness. Learning environment is not only about physical facilities but also social and psychological condition. The complexity of clinical learning environments pose challenges and problems that may affect students learning process so it is necessary to monitoring and evaluating students learning environments. This study aims to assess students' perception of their learning environment and the effect of primary, secondary and tertiary health care services utilization as clinical learning environments.
\end{abstract}

Method: This study was conducted with a cross sectional study design. The subjects were 36 students of obstetrics and gynecology department. Data obtained from learning environment questionnaires in tertiary, secondary and primary health care services. A non-parametric test was applied to compared learning environment score in each health care level.

Results: Students perception of their learning environment between tertiary and secondary as well as tertiary and primary health care services were significantly different. Students stated advantages and disadvantages of each learning environment that can affect their competence level.

Conclusion: Students have a good perception of the their learning environment. There was significant difference between tertiary and two other health care services.

Keywords: self-perceived competence, learning environment, health care services

\begin{abstract}
ABSTRAK
Latar belakang: Lingkungan belajar klinik memiliki peran penting dalam proses belajar mahasiswa sehingga dapat pula mempengaruhi penguasaan kompetensi serta kesiapan praktik lulusan. Lingkungan belajar klinik tidak hanya berupa lingkungan fisik namun juga sosial dan psikologikal. Kompleksitas lingkungan belajar klinik dapat menimbulkan kendala dan tantangan tersendiri pada proses pelaksanaan pendidikan tahap profesi sehingga perlu dilakukan proses pengawasan dan evaluasi terhadap lingkungan belajar mahasiswa. Tujuan penelitian ini adalah untuk mengetahui persepsi mahasiswa mengenai layanan kesehatan primer, sekunder,dan tersier sebagai lingkungan belajar klinik.

Metode: Penelitian ini dilakukan dengan desain cross sectional study. Subjek penelitian adalah 36 mahasiswa kepaniteraan ilmu kebidanan dan penyakit kandungan FK Undip yang menjalani kepaniteraan di layanan kesehatan tersier-sekunder-primer. Data diperoleh dari kuesioner lingkungan belajar mahasiswa pada masing-masing layanan kesehatan. Uji non parametrik Friedman test dan Wilcoxon test digunakan untuk menguji beda skor masing-masing layanan kesehatan.
\end{abstract}

contact: diandhamana@gmail.com 
Hasil: Mahasiswa memiliki persepsi yang berbeda mengenai ketiga lingkungan belajarnya. Meskipun demikian perbedaan bermakna terdapat antara skor lingkungan belajar di layanan kesehatan tersier dan sekunder serta tersier dan primer. Mahasiswa memiliki pendapat mengenai kelebihan dan kekurangan di masing-masing layanan kesehatan.

Kesimpulan: Mahasiswa memiliki persepsi yang baik mengenai lingkungan belajar di ketiga layanan kesehatan. Terdapat perbedaan persepsi mahasiswa mengenai ketiga lingkungan belajar tersebut. Masingmasing layanan kesehatan memiliki kelebihan dan kekurangan.

Kata kunci: lingkungan belajar, klinik, tipe layanan kesehatan

\section{PENDAHULUAN}

Pentingnya lingkungan belajar terhadap proses pembelajaran mahasiswa telah diketahui secara luas. ${ }^{1,2,3}$ Lingkungan belajar yang kondusif dikatakan dapat mempengaruhi motivasi belajar dan hasil belajar mahasiswa. Lingkungan belajar klinik dijabarkan sebagai segala sesuatu yang terdapat dalam konteks klinik yang dapat mempengaruhi capaian mahasiswa. ${ }^{4,5}$ Metode pembelajaran dan penilaian yang digunakan serta faktor sosial dan psikologis karena interaksi mahasiswa dengan dosen, sesama mahasiswa dan pihak lain di layanan kesehatan juga merupakan komponen lingkungan belajar. $^{6}$

Tercapainya kompetensi mahasiswa sesuai standar yang telah ditetapkan merupakan hasil belajar yang diharapkan pada proses pendidikan kedokteran. Pencapaian standar kompetensi tersebut tidak terlepas dari proses pendidikan tahap profesi/ klinik. Pada pendidikan tahap profesi mahasiswa diberikan pengalaman belajar langsung pada sistem layanan kesehatan sehingga selain peningkatan penguasaan kompetensi, diharapkan pula terjadi peningkatan kesiapan lulusan dalam memberikan pelayanan kesehatan.

Kondisi lingkungan belajar klinik yang dipengaruhi oleh banyak faktor dapat menimbulkan tantangan dan kendala dalam pelaksanaan proses pembelajaran tahap profesi. Beberapa tantangan yang dapat dijumpai pada pendidikan tahap profesi berupa keterbatasan waktu, situasi yang tidak dapat diprediksi, serta lingkungan yang kurang nyaman untuk proses pembelajaran. ${ }^{7}$ Situasi yang tidak dapat di presiksi terutama berkaitan dengan ketersediaan jumlah dan variasi kasus/penyakit yang sesuai dengan level kompetensi. Jumlah mahasiswa yang semakin meningkat juga mempengaruhi rasio mahasiswa: kasus/ penyakit yang tersedia. ${ }^{5}$

Kendala pada pendidikan tahap profesi yang sering dijumpai adalah kurang jelasnya learning objectives, partisipasi aktif mahasiswa, latihan problem solving, observasi langsung dan umpan balik terhadap aktivitas mahasiswa, waktu untuk refleksi dan diskusi serta kurang kongruennya program pembelajaran tahap profesi dengan kurikulum yang ada. ${ }^{8}$ Tantangan dan kendala pada pendidikan tahap profesi perlu mendapat perhatian dari institusi pendidikan kedokteran.

Salah satu tantangan yang banyak dikhawatirkan adalah mengenai ketersediaan jumlah dan variasi kasus pasien yang sesuai dengan level kompetensi berdasarkan Standar Kompetensi Dokter Indonesia. ${ }^{9}$ Jumlah dan variasi kasus yang terbatas akan mempengaruhi pengalaman mahasiswa dan akan berdampak pada tingkat penguasaan kompetensinya. ${ }^{10}$ Berdasarkan Standar Pendidikan Profesi Dokter Indonesia, institusi pendidikan kedokteran wajib memastikan ketersediaan sumber daya yang dibutuhkan dalam penyelenggaraan pendidikan. Selain ketersediaaan rumah sakit sebagai wahana pendidikan dan staf pendidik, jumlah dan variasi kasus yang dihadapi mahasiswa tahap profesi juga harus bervariasi. ${ }^{11}$

Jumlah dan variasi kasus/ penyakit yang tersedia tidak terlepas dari layanan kesehatan yang digunakan sebagai wahana pendidikan. Sesuai dengan ketetapan pemerintah, tipe rumah sakit yang dapat menjadi rumah sakit pendidikan utama 
suatu institusi pendidikan kedokteran adalah rumah sakit tipe $\mathrm{A}$ dan tipe $\mathrm{B}$ dengan ketentuan tertentu. ${ }^{12}$ Meski awalnya rumah sakit pendidikan utama masih mampu menyediakan jumlah dan variasi kasus, namun dengan bertambah pesatnya jumlah mahasiswa kedokteran, muncul kekhawatiran mengenai ketersediaan jumlah dan variasi kasus yang dapat disediakan rumah sakit pendidikan utama.

Selain penambahan jumlah mahasiswa, penerapan sistem Jaminan Kesehatan Nasional (JKN) juga dapat mempengaruhi ketersediaan kasus/ penyakit di rumah sakit pendidikan utama. JKN memberikan pelayanan kesehatan bertingkat melalui sistem rujukan. Layanan kesehatan tingkat pertama/ primer berupa puskesmas, praktik dokter/ dokter gigi, klinik pratama dan RS tipe D pratama sedangkan layanan kesehatan sekunder dan tersier termasuk ke dalam layanan rujukan lanjutan. Pada penerapan sistem JKN, kasus yang merupakan kompetensi pelayanan kesehatan tingkat primer harus dapat diselesaikan di layanan kesehatan tingkat pertama kecuali ada keterbatasan sumber daya atau sarana dan prasarana.

Kekhawatiran akan ketersediaan jumlah/kasus yang semakin menurun/ tidak sesuai kompetensi mahasiswa membuat banyak institusi kemudian bekerjasama dengan rumah sakit daerah dan puskesmas sebagai wahana pendidikan jejaring untuk dapat menjaga mutu pendidikan dan lulusan. Penggunaan wahana pendidikan jejaring di masingmasing institusi pendidikan kedokteran bervariasi tergantung kondisi lingkungan belajar masingmasing. Terdapat institusi yang menggunakan kombinasi RS pendidikan utama-RS daerah, RS pendidikan utama-puskesmas, serta ada yang menggunakan kombinasi ketiganya untuk dapat mendukung tercapainya kompetensi mahasiswa sesuai standar yang telah ditetapkan.

Meskipun lingkungan belajar di RS daerah dan puskesmas dipandang memiliki kelebihan terutama pada kasus/penyakit yang tersedia, namun perlu juga dipertimbangkan mengenai komponen lingkungan belajar klinik lainnya seperti supervisi, kegiatan belajar mengajar dan penilaian cenderung lebih baik di RS pendidikan utama. ${ }^{13}$ Selain itu, tantangan berupa tidak dapat di prediksinya situasi di lapangan dapat juga terjadi pada semua layanan kesehatan. Penggunaan berbagai tipe/tingkat layanan kesehatan sebagai wahana pendidikan tahap profesi diharapkan dapat saling melengkapi kekurangan masing-masing dan didapatkan kondisi lingkungan belajar yang optimal dalam pencapaian kompetensi mahasiswa.

Berdasarkan pentingnya peran lingkungan belajar klinik terhadap proses belajar mahasiswa, monitoring dan evaluasi perlu dilakukan untuk mengetahui apakah lingkungan belajar klinik pada wahana pendidikan yang digunakan masih sesuai untuk memfasilitasi pendidikan klinik mahasiswa. Tujuan dari penelitian ini adalah untuk mengetahui persepsi mahasiswa mengenai lingkungan belajar pada yankes tersier, sekunder dan primer.

\section{METODE}

Penelitian menggunakan desain cross sectional study dengan pengisian kuesioner lingkungan belajar dan tingkat kompetensi mahasiswa. Penilaian pada kuesioner menggunakan skala likert. Kuesioner lingkungan belajar terdiri dari 4 kategori yaitu kondisi belajar, aktivitas dan sumber belajar, kesempatan belajar dan penilaian. ${ }^{14}$

Penelitian dilakukan pada kepaniteraan ilmu kebidanan dan penyakit kandungan FK Undip yang telah menggunakan layanan kesehatan primer, sekunder dan tersier sebagai wahana pendidikannya. Subjek penelitian adalah mahasiswa yang menjalani kepaniteraan ilmu kebidanan dan penyakit kandungan FK Undip. Semua subjek menjalani perlakuan yang sama yaitu kepaniteraan di layanan kesehatan tersier (RS Pendidikan Utama/RSPU) selama 6 minggu, di layanan kesehatan sekunder (RS Jejaring) dan primer (puskesmas) masingmasing selama 1 minggu. Sebanyak 36 mahasiswa (4 periode kepaniteraan) bersedia menjadi responden dalam penelitian ini.

Penjelasan mengenai penelitian, informed consent, penjelasan mengenai pengisian kuesioner serta pengisian kuesioner tidak dapat dilakukan secara bersamaan untuk semua responden karena berbenturan dengan padatnya kegiatan 
kepaniteraan sehingga peneliti mengumpulkan responden dalam kelompok-kelompok kecil.

\section{HASIL DAN PEMBAHASAN}

\section{Kondisi belajar}

Terdapat 7 skala pada kuesioner lingkungan belajar yaitu otonomi, supervisi, dukungan sosial, beban kerja, kejelasan peran, proses belajar mengajar dan variasi kasus dengan total 28 item penyataan yang dinilai dengan skala likert 1 (sangat tidak setuju) hingga 5 (sangat setuju). Semakin tinggi skor maka persepsi mahasiswa semakin baik. Meski hanya dilaksanakan selama masing-masing 1 minggu, persepsi mahasiswa terhadap kondisi belajar di RS Jejaring dan puskesmas lebih baik dari pada RSPU (Tabel 1).

Tabel 1. Skor total kondisi belajar di ketiga layanan kesehatan $(n=36)$

\begin{tabular}{lcccc} 
& Nilai terendah & Nilai Tertinggi & Mean & Standar deviasi \\
RS Pendidikan Utama & 58 & 114 & 92,1 & 10,9 \\
RS Jejaring & 67 & 140 & 96,9 & 12,9 \\
Puskesmas & 73 & 125 & 95,9 & 13,2 \\
\hline
\end{tabular}

Skala otonomi, proses belajar mengajar dan variasi kasus merupakan skala kondisi belajar yang menunjukkan perbedaan bermakna $(p<0,05)$ seperti pada Tabel 2. Perbedaan pada ketiga skala terdapat antara skor RSPU dengan RS Jejaring dan antara RSPU dengan puskesmas. Skala otonomi dan variasi kasus pada RS jejaring dan puskesmas lebih baik daripada RSPU namun skala proses belajar mengajar RSPU lebih baik daripada RS jejaring dan puskesmas. ${ }^{13,15}$

Tabel 2. Kondisi Pembelajaran di ketiga lokasi kepaniteraan $(n=36)$

\begin{tabular}{lcccc} 
& Nilai $\mathbf{p}$ & \multicolumn{3}{c}{ Mean \pm SD } \\
\cline { 3 - 5 } & & RSPU & RS Jejaring & Puskesmas \\
\hline Otonomi & .005 & $3.01 \pm 1.01$ & $3.46 \pm 1.00$ & $3.51 \pm 0.93$ \\
Supervisi & .162 & $3.48 \pm 0.93$ & $3.38 \pm 0.90$ & $3.29 \pm 0.88(\sim)$ \\
Dukungan Sosial & .081 & $3.66 \pm 0.84$ & $3.45 \pm 0.95$ & $3.55 \pm 0.79(*)$ \\
Beban Kerja & .156 & $3.11 \pm 1.01$ & $3.29 \pm 0.91(\sim)$ & $3.40 \pm 1.08$ \\
Kejelasan Peran & .938 & $3.53 \pm 0.84$ & $3.51 \pm 0.93$ & $3.51 \pm 0.90$ \\
Proses Belajar Mengajar & .000 & $3.95 \pm 0.73(*)$ & $3.58 \pm 0.93(*)$ & $3.35 \pm 0.96$ \\
Variasi Kasus & .000 & $2.96 \pm 0.86(\sim)$ & $3.52 \pm 0.87$ & $3.33 \pm 0.90$ \\
\hline
\end{tabular}

Keterangan: $(*)$ rata-rata tertinggi

$(\sim)$ rata-rata terendah

Berdasarkan jawaban mahasiswa, kemandirian/ otonomi menjadi faktor yang paling membedakan lingkungan belajar di layanan kesehatan primer dan sekunder dengan lingkungan belajar di layanan kesehatan tersier. ${ }^{16}$ Kemandirian saat menangani pasien pada lingkungan klinik mempengaruhi perkembangan mahasiswa. ${ }^{17}$ Kurangnya variasi kasus dapat mempengaruhi kesempatan berlatih dan juga mempengaruhi kompetensi mahasiswa. ${ }^{18,19}$
Meski mayoritas responden memiliki persepsi yang baik mengenai lingkungan belajar kepaniteraan ilmu kebidanan dan penyakit kandungan namun berdasarkan uji statistik didapatkan perbedaan bermakna pada persepsi mahasiswa mengenai lingkungan belajar di ketiga layanan kesehatan $(\mathrm{p}=0,008)$. Persepsi mahasiswa mengenai lingkungan belajar di layanan kesehatan primer dan sekunder lebih baik daripada persepsi mereka 
mengenai lingkungan belajar di layanan kesehatan tersier. Mahasiswa lebih menyukai lingkungan belajar di layanan kesehatan primer dan sekunder dibanding RS rujukan tersier yang lebih besar karena mereka merasa bahwa suasana di RS kecil lebih suportif, rileks dan kondusif untuk proses belajar mereka. ${ }^{20}$

\section{Aktivitas dan sumber belajar}

Terdapat 17 pernyataan mengenai aktivitas dan sumber belajar yang harus dinilai oleh responden menggunakan skala likert $(0=$ tidak tersedia; $1=$ kurang; 2 = cukup; $3=$ lebih dari yang dibutuhkan). Sebanyak $83,5 \%$ responden menyatakan bahwa ketersediaan aktivitas dan sumber belajar di layanan kesehatan tersier (RSPU) sudah cukup dan lebih dari yang dibutuhkan. Persentase ini menurun pada layanan kesehatan sekunder (59\%) dan primer (54,7\%). Perbandingan persentase yang sama terlihat pada nilai rata-rata skala proses belajar mengajar pada kondisi belajar.

Rendahnya persentase aktivitas dan sumber belajar di RS jejaring dan puskesmas dapat di pengaruhi oleh karena tidak adanya aktivitas belajar terstruktur seperti saat di RSPU atau karena proses supervisi yang lebih banyak dilakukan oleh bidan. Mahasiswa memiliki persepsi yang lebih baik mengenai instruksi serta umpan balik yang diberikan residen maupun dosen klinik daripada instruksi dan umpan balik yang diberikan oleh petugas kesehatan lain. ${ }^{21}$

\section{Kesempatan berlatih}

Kesempatan berlatih diukur berdasarkan kesempatan responden untuk berlatih ketrampilan langsung ke pasien. Terdapat 62 ketrampilan yang berhubungan dengan ilmu kebidanan dan penyakit kandungan. Penilaian menggunakan skala likert 1 hingga 6 sebagai berikut:

$1=$ tidak didemonstrasikan oleh pembimbing dan tidak dilakukan oleh mahasiswa

2 = didemonstrasikan oleh pembimbing tapi tidak dilakukan oleh mahasiswa

$3=1-3$ kali kesempatan dilakukan oleh mahasiswa

$4=4-6$ kali kesempatan dilakukan oleh mahasiswa

$5=7-9$ kali kesempatan dilakukan oleh mahasiswa

$6=10$ kali atau lebih kesempatan dilakukan oleh mahasiswa

Kesempatan berlatih mahasiswa sangat bervariasi untuk tiap ketrampilan di tiap layanan kesehatan. Data kesempatan berlatih untuk tiap kelompok ketrampilan dirangkum sesuai persentase mahasiswa pada tabel 3. Secara umum, kesempatan berlatih ketrampilan di RSPU (layanan kesehatan tersier) jauh lebih tinggi jika dibandingkan dengan layanan kesehatan sekunder dan primer. Hal ini dapat disebabkan karena lama waktu kepaniteraan di RS pendidikan utama lebih lama (6 minggu) jika dibandingkan dengan kepaniteraan di RS Jejaring dan puskesmas (masing-masing 1 minggu). Berdasarkan jawaban mahasiswa pada pertanyaan terbuka penyebab kurangnya berlatih dapat akibat dari mahasiswa sendiri yang malas atau kurang aktif, atau dari luar mahasiswa seperti kebijakan RS (akreditasi RS/layanan kesehatan), terdapat mahasiswa lain yang praktik di tempat yang sama dan perawat/ bidan/ residen yang lebih suka mengerjakan sendiri. 


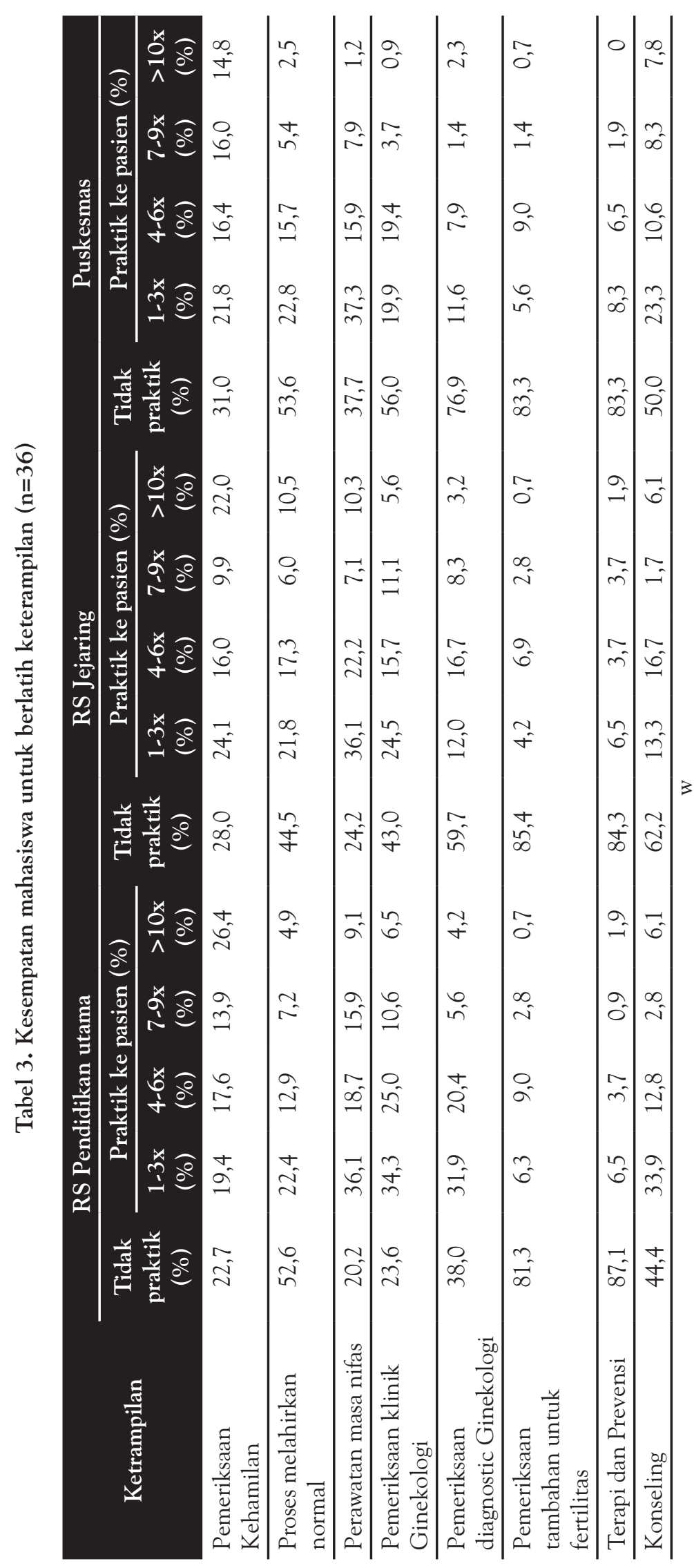




\section{Penilaian}

Jenis penilaian yang sering digunakan di layanan kesehatan tersier (7 jenis) lebih banyak dibandingkan dengan layanan kesehatan sekunder dan primer ( 3 jenis). Jenis penilaian yang sering digunakan dapat dilihat pada Tabel 4 .

Tabel 4. Jenis penilaian yang sering digunakan $(n=36)$
Rumah Sakit Pendidikan Utama Rumah Sakit Jejaring Puskesmas
1. OSCE
1. Ujian lisan kelompok
1. Presentasi Kasus
2. Log book
2. Log book
2. Pembuatan makalah
3. Presentasi kasus
3. Ujian lisan individual
3. Log book
4. Ujian lisan kelompok
5. Ujian lisan individual
6. Ujian tertulis
7. Pembuatan makalah/ tugas

Tampak bahwa jenis penilaian workplace-based untuk menilai performa mahasiswa seperti miniCEX belum digunakan pada ketiga layanan kesehatan tersebut. Penilaian pada pendidikan klinik seharusnya dilakukan untuk menilai performa ketrampilan mahasiswa pada level "does" menurut piramida Miller. ${ }^{20,21}$ Penilaian dilakukan berdasarkan hasil observasi langsung pada performa mahasiswa saat mengangani pasien secara komprehensif. Penilaian dapat berdampak pada proses belajar dan capaian kompetensi mahasiswa melalui proses pemberian umpan balik sehingga perlu dipertimbangkan pemilihan dan penerapan penilaian yang sesuai. ${ }^{22}$

Meskipun pada kenyataannya jenis penilaian yang di terapkan masih belum sesuai untuk menilai level "does", mayoritas mahasiswa berpendapat bahwa penilaian yang dilakukan telah sesuai dengan penguasaan ketrampilan, adil dan berdasarkan pengalaman mahasiswa serta telah sesuai dengan tujuan utama kepaniteraan. Penjelasan mengenai penilaian menurut responden diberikan dengan lebih jelas saat di RS Pendidikan Utama.

\section{Kelebihan dan kekurangan layanan kesehatan tersier, sekunder dan primer}

Selain menggunakan kuesioner, responden ditanya lebih lanjut mengenai kelebihan dan kekurangan tiap lingkungan belajar menggunakan pertanyaan terbuka. Kelebihan dan kekurangan ini perlu dipertimbangkan agar dapat menciptakan lingkungan belajar yang optimal mendukung tercapainya kompetensi mahasiswa ${ }^{23,24,25}$. Berdasarkan jawaban responden didapatkan 7 perbedaan lingkungan belajar pada ketiga layanan kesehatan yang digunakan (Tabel 5). 
Tabel 5. Persepsi mahasiswa mengenai kelebihan dan kekurangan lingkungan belajar masing-masing tipe layanan kesehatan $(n=36)$

\begin{tabular}{|c|c|c|c|}
\hline & RS Pendidikan utama & RS Jejaring & Puskesmas \\
\hline $\begin{array}{l}\text { Bimbingan/ } \\
\text { Supervisi }\end{array}$ & $\begin{array}{l}\text { Terutama oleh residen, dosen } \\
\text { pembimbing susah ditemui diluar } \\
\text { jadwal bimbingan }\end{array}$ & $\begin{array}{l}\text { Kurang, bila ada visite } \\
\text { bangsal }\end{array}$ & $\begin{array}{l}\text { Kurang, bimbingan } \\
\text { dilakukan oleh bidan }\end{array}$ \\
\hline $\begin{array}{l}\text { Kegiatan belajar } \\
\text { mengajar }\end{array}$ & $\begin{array}{l}\text { Banyak dan terjadwal dengan } \\
\text { baik }\end{array}$ & $\begin{array}{l}\text { Tidak terjadwal, tidak ada } \\
\text { kegiatan di poli rawat jalan }\end{array}$ & $\begin{array}{l}\text { Tidak terjadwal, jarang ada } \\
\text { kegiatan diluar jam kerja }\end{array}$ \\
\hline Ketersediaan kasus & $\begin{array}{l}\text { Jumlah kasus banyak namun } \\
\text { tidak sesuai dengan kompetensi }\end{array}$ & $\begin{array}{l}\text { Jumlah kasus banyak dan } \\
\text { sesuai kompetensi (partus } \\
\text { normal) }\end{array}$ & $\begin{array}{l}\text { Banyak pasien ANC, } \\
\text { kehamilan normal di poli. } \\
\text { Partus normal sedikit/ } \\
\text { tidak ada }\end{array}$ \\
\hline $\begin{array}{l}\text { Kesempatan } \\
\text { berlatih }\end{array}$ & $\begin{array}{l}\text { Terdapat kesempatan untuk } \\
\text { berlatih beberapa ketrampilan } \\
\text { umum/tidak tergantung jenis } \\
\text { kasus/penyakit. Namun kelelahan } \\
\text { dan akreditasi RS membatasi } \\
\text { kesempatan tersebut. }\end{array}$ & $\begin{array}{l}\text { Cukup namun harus } \\
\text { berebut dengan mahasiswa } \\
\text { koas universitas lain dan } \\
\text { mahasiswa kebidanan }\end{array}$ & $\begin{array}{l}\text { Sangat tergantung } \\
\text { ketersediaan pasien }\end{array}$ \\
\hline $\begin{array}{l}\text { Kemandirian } \\
\text { menangani pasien }\end{array}$ & $\begin{array}{l}\text { Kurang, tergantung residen dan } \\
\text { karena akreditasi RS }\end{array}$ & $\begin{array}{l}\text { Baik, terkadang bidan } \\
\text { langsung mengambil alih } \\
\text { penanganan }\end{array}$ & Sangat baik \\
\hline $\begin{array}{l}\text { Hubungan dengan } \\
\text { rekan kerja }\end{array}$ & Baik & Tidak terlalu baik & Cukup baik \\
\hline $\begin{array}{l}\text { Sarana dan } \\
\text { Prasarana }\end{array}$ & Lebih baik & Cukup & $\begin{array}{l}\text { Kurang, terutama berkaitan } \\
\text { dengan tempat tinggal koas }\end{array}$ \\
\hline
\end{tabular}

\section{KESIMPULAN}

Persepsi mahasiswa mengenai lingkungan belajar kepaniteraan ilmu kebidanan dan penyakit kandungan FK Undip cukup baik. Persepsi mahasiswa mengenai lingkungan belajar di layanan kesehatan primer dan sekunder lebih baik daripada persepsi lingkungan belajar di layanan kesehatan tersier. Aspek otonomi/ kemandirian memiliki peran penting dalam lingkungan belajar berdasarkan persepsi mahasiswa. Ketiga lingkungan belajar memiliki kelebihan masing-masing yang dapat di optimalkan oleh institusi pendidikan agar dapat menciptakan keseluruhan lingkungan belajar yang lebih baik lagi untuk mendukung pencapaian kompetensi mahasiswa serta kekurangan yang harus diperhatikan oleh institusi agar tidak menghambat capaian kompetensi mahasiswa.

\section{SARAN}

Hasil dari penelitian ini dapat digunakan institusi sebagai langkah awal dalam proses evaluasi lingkungan belajar klinik serta sebagai dasar pengambilan kebijakan untuk meningkatkan kualitas lingkungan belajar mahasiswa. Proses pengawasan dan evaluasi pada lingkungan belajar klinik perlu dilakukan secara teratur dan berkelanjutan agar dapat terus mendukung pencapaian kompetensi mahasiswa. Pemilihan layanan kesehatan perlu mendapatkan perhatian tersendiri. Layanan kesehatan yang dipilih sebagai jejaring hendaknya yang dapat memberikan kesempatan berlatih yang lebih atau yang tidak bisa didapatkan di Rumah Sakit Pendidikan Utama.

Penelitian ini dapat dilanjutkan pada periode kepaniteraan yang berbeda agar didapatkan data mengenai ketersediaan kasus/ penyakit pada masingmasing layanan kesehatan dalam satu periode waktu yang panjang agar didapatkan data yang lebih komprehensif mengenai lingkungan belajar mahasiswa. Penelitian kualitatif dapat dilakukan untuk menggali lebih lanjut terutama mengenai kekurangan yang dikemukakan oleh mahasiswa 
mengenai lingkungan belajarnya dan bagaimana kondisi lingkungan belajar tersebut mempengaruhi capaian kompetensi mereka.

\section{DAFTAR PUSTAKA}

1. Lai NM, Nalliah S, Jutti RC, Hla YY, Lim VKE. The educational environment and self-perceived clinical competence of senior medical students in malaysian medical school. Educ Health. 2009; 22(2).

2. Genn JM. AMEE Medical Education Guide No. 23 (Part 1): Curriculum, environment, climate, quality and change in medical education-a unifying perspective. Med Teach. 2001; 23(4): 337-44.

3. Hutchinson L. Educational environment. BMJ. 2003; 326(7393): 810-2.

4. Leman. Persepsi mahasiswa mengenai lingkungan belajar, motivasi belajar, strategi belajar, dan hasil belajar di Fakultas Kedokteran Universitas Gadjah Mada Yogyakarta. M.Med.Ed.tesis. 2014. Universitas Gadjah Mada.

5. Emilia O. Kompetensi dokter dan lingkungan belajar klinik di rumah sakit. Yogyakarta: Gadjah Mada University Press; 2008.

6. Thistlethwaite J. Learning Environment. In: Cantillon P, Wood D, editors. ABC of Learning and Teaching in Medicine. London: John Wiley \& Sons Ltd; 2010. 60-3.

7. Ramani S, Leinster S. AMEE Guide no. 34: teaching in the clinical environment. Med Teach. 2008; 30(4): 347-64.

8. Spencer J. Learning and teaching in the clinical environment. BMJ. 2003; 326: 591-4.

9. Konsil Kedokteran Indonesia. Standar Kompetensi Dokter Indonesia, 2nd ed, Jakarta. 2012.

10. Stewart J, O'Halloran C, Barton JR, Singleton SJ, Harrigan P, Spencer J. Clarifying the concepts of confidence and competence to produce appropriate self-evaluation measurement scales. Med Educ. 2000; 34: 903-9.

11. Konsil Kedokteran Indonesia. Standar Pendidikan Profesi Dokter Indonesia, 2nd ed, Jakarta. 2012.

12. Menteri Kesehatan Republik Indonesia. Peraturan Menteri Kesehatan Republik Indonesia Nomor 1045/MENKES/PER/XI/2006 tentang Pedoman organisasi rumah sakit di lingkungan departemen kesehatan

13. Jaschinski J, deVilliers MR. Factors influencing the development of practical skills of interns working in regional hospitals of the Western Cape province of South Africa. SA Fam Pract. 2008; 50(1): 70.
14. Emilia O. The relationship between the clinical learning environment and the approaches to learning of medical students. PhD.thesis. The University of New South Wales. 2003.

15. Tokuda Y, Goto E, Otaki J, Jacobs J, Omata F, Saphiro M. Educational environment of university and non-university hospitals in Japan. Int J Med Educ. 2010; 1: 10-4.

16. Gupta TKS, Murray RB, McDonell A, Murphy B, Underhill AD. Rural internships for final year students: clinical experience, education and workforce. Rural Remote Health. 2008; 8: 827.

17. Salminen H, Ohman E, Stenfors-Hayes T. Medical students' feedback regarding their clinical learning environment in primary healthcare: a qualitative study. BMC Med Educ. 2016; 16: 313.

18. Dehmer JJ, Amos KD, Farrel TM, Meyer AA, Newton WP, Meyers MO. Competence and confidence with basic procedural skills: The experience and opinions of fourth year medical students at a single institution. Acad Med. 2013; 88(5): 682-7.

19. Kim JY, Myung SJ. Could clinical experience during clerkship enhance students' clinical performance? BMC Med Educ. 2014; 14: 209.

20. Bennet D, Kelly M, O'Flynn S. Are the bigger hospital better: DREEM on?. Ir J Med Sci. 2010; 179: 515-9.

21. Van Hell EA, Kuks JBM, Raat AN, van Lohuizen MT, Cohen-Schotanus J. Instructiveness of feedback during clerkship: influence of supervisor, observation and student initiative. Med Teach. 2009; 31: 45-50.

22. Epstein RM. Assessment in medical education. N Engl J Med. 2007; 356(4): 387-96.

23. Church MA, Elliot AJ, Gabble SL. Perception of classroom environment achievement goals and achievement outcomes. J Educ Psychol. 2001; 93(1): 43-54.

24. Shimizu T, Tsugawa Y, Tanoue Y, Konishi R, Nishizaki Y, Kishimoto M.

25. The hospital educational environment and performance in residents in general medicine intraining examination: a multicenter study in Japan. Int J Gen Med. 2013; 6: 637-40.

26. Khurseed I, Baig L. Students' perceptions of educational environment of a private medical school in Pakistan. JPMA. 2014; 64(11): 1244-9. 